Meta

Journal des traducteurs

Translators' Journal

\title{
What Do We Know About a Translator's Day?
}

\section{Louise Hébert-Malloch}

Volume 49, numéro 4, décembre 2004

URI : https://id.erudit.org/iderudit/009805ar

DOI : https://doi.org/10.7202/009805ar

Aller au sommaire du numéro

Éditeur(s)

Les Presses de l'Université de Montréal

ISSN

0026-0452 (imprimé)

1492-1421 (numérique)

Découvrir la revue

Citer cette note

Hébert-Malloch, L. (2004). What Do We Know About a Translator's Day? Meta, 49(4), 973-979. https://doi.org/10.7202/009805ar

\section{Résumé de l'article}

Nous disposons de peu de renseignements au sujet de la journée de travail régulière d'un traducteur. Pour combler cette lacune, le travail d'un traducteur a été filmé pendant environ 5 semaines. Les enregistrements ont ensuite été analysés sur les plans macroscopique et microscopique. La première analyse a révélé des données d'ordre général alors que la deuxième tentait, entre autres, de mettre en lumière les stratégies utilisées dans le cadre de son travail. Cet article est le résumé d'une maîtrise en traduction soutenue en 1999 au Collège Glendon de l'University York.
Ce document est protégé par la loi sur le droit d'auteur. L'utilisation des services d’Érudit (y compris la reproduction) est assujettie à sa politique d'utilisation que vous pouvez consulter en ligne.

https://apropos.erudit.org/fr/usagers/politique-dutilisation/ 


\section{What Do We Know About a Translator's Day?}

\section{RÉSUMÉ}

Nous disposons de peu de renseignements au sujet de la journée de travail régulière d'un traducteur. Pour combler cette lacune, le travail d'un traducteur a été filmé pendant environ 5 semaines. Les enregistrements ont ensuite été analysés sur les plans macroscopique et microscopique. La première analyse a révélé des données d'ordre général alors que la deuxième tentait, entre autres, de mettre en lumière les stratégies utilisées dans le cadre de son travail. Cet article est le résumé d'une maîtrise en traduction soutenue en 1999 au Collège Glendon de I'University York.

\begin{abstract}
Little is known about a translator's day. I therefore undertook to videotape a professional translator's work for approximately 5 weeks. The tapes were then analyzed both at a macroscopic and a microscopic level. The first analysis produced information about general characteristics of his work whereas the second tried to uncover things such as strategies used in problem solving. This article is the summary of a Master's Thesis defended in 1999 at Glendon College, York University.
\end{abstract}

\section{MOTS-CLÉS/KEYWORDS}

translator's day, problem-solving, strategies, translation process

\section{INTRODUCTION}

There have been relatively few studies in processrelated translation studies. Authors have long complained that the process of translation has not been addressed. For example, Lörscher (1992a) concluded that little attention has been given to the process of translation or to translators' actual performance. In 1996, Fraser actually searched the literature on the subject and found that: "There now exists a small but growing body of literature on what has come to be known as 'translation process analysis': a method of studying the mental processes of translation on the basis of some form of introspection" (Fraser 1993, 1994, 1996a, 1996b); Gerloff 1988; Jääskeläinen 1987, 1993; Königs 1987; Krings 1986; Lörscher 1991, 1992a, 1992b, 1993; Séguinot 1989, 1991; Tirkkonen-Condit 1989). There have been others since then (Séguinot 1996, Königs and Kaufmann, 1996, Jääskeläinen 1996, Tirkkonen-Condit 1997, and Gile's 1995 study of interpreters. The majority, if not all of these studies, tried to understand the process by means of introspection, defined by Fraser as a way of eliciting data by asking a translator to verbalize while he is translating. The verbalizations are then taped and the protocols (hence the name "thinking-aloud protocols or TAPS") are then analyzed. The majority of the studies compared the performance of different groups of people, such as students, bilinguals and professional translators. Only one study (Séguinot 1989) focused on a single professional translator. However, I was not convinced of the validity of the data elicited by the TAPs because of the possibility that it is susceptible to personal bias. Toury (1995) mentioned the possibility of interference between the oral and written modes of translation. I also suspected that the need to explain one's actions while performing them could introduce an element of error and slow down the process, thus deforming it. There is no doubt that TAPs produce interesting and useful data. However, I decided to study the process of translation using a less intrusive method.

\section{METHODOLOGY}

A case study approach was taken, since this kind of research is largely lacking. I studied a translator's work directly in his natural environment, i.e. at work, during his normal work day. At the time, I was doing my master's thesis and working at the Federal Government's Translation Bureau. Permission to study a colleague was granted, a volunteer came forward and we were on our way. I hooked up the translator's workstation to a videorecorder and recorded his work directly onto videotape after having installed a special video card in his computer. The reasoning behind this method was simple. The main concern was to record data in the most unobtrusive way possible. This meant not videotaping the translator directly but, rather, his work. To this end, I needed to record directly from the computer to the videorecorder. I would therefore not see the translator himself, and he would, at least I hoped he would, feel less 'invaded.' Also, not having to verbalize what he did (which seemed completely unnatural) might produce data less likely to be affected by bias. The work being done was real work (as opposed to giving a group of people an article from a newspaper and asking them to translate it for a study), the constraints under which the translator had to work were real. Unfortunately, I was not able to see the translator do various tasks such as talk on the phone or consult a dictionary or colleague (an advantage for the TAPs).

The translator was taped during working hours, that is, approximately $7 \frac{1}{2}$ hours a day, for a period of five weeks or 26 days (he was taped for a week prior to the start so he could get used to the process but these tapes were not studied). Fiftytwo videotapes were recorded of his work (a total of approximately 152 hours of taping). 


\section{ANALYSIS}

The translation process was analysed on two different levels called macroscopic and microscopic. The macroscopic level was designed to reveal the individual characteristics of the translator in his work habits, focussing on variables such as number of hours worked, number of words translated, speed of translation and the number of pauses taken. The microscopic analysis examined several texts in detail to reveal certain linguistic characteristics in his work indicative of different constraints, either self-imposed or imposed by others and of individual preferences. By nature, the macroscopic level lends itself to generalization. The microscopic structures are accessed more analytically; therefore they become easily fragmented. The sheer number of fragments precluded any hope of final treatment. Selection was inevitable.

\section{MACROSCOPIC ANALYSIS}

In the first part of the study, I viewed the 52 tapes and recorded on paper data which could then be transferred to an Excel worksheet for analysis. The work had to be broken down into large units (days) and these, in turn, into smaller units, allowing for a more detailed account of the work. The units were separated by pauses, the shortest being arbitrarily set at 3 minutes (see infra).

\section{RESULTS}

During the 26 days of this study, 40 texts were translated totalling 32,469 words for 12 different federal government departments. Of the 40 texts, 23 had 500 words or fewer. Only one was considered 'long,' totalling over 5000 words.

The bulk of the work thus consisted of short texts ( 0 to 500 words). The data showed that the translator worked on a maximum of 6 texts in a day, and on a minimum of 1 (in the case of longer jobs).

I analyzed 151 hours 47 minutes of the translator's time, during which he made 231 pauses for a total of 89 hours 14 minutes, that is for $59 \%$ of his time. He translated 32,469 words in 26 days, thus an average of 1248 words a day, or 166 words per hour. This speed was called the 'theoretical speed' and appeared somewhat low. It was a surprising result because I knew from personal experience that this person was a good 'producer' (this is what translators were called at the Bureau at the time and perhaps still are).

It was decided to determine if this was the subject's real speed or if there was a more precise way of calculating an individual translator's speed. I already knew that he had translated (as could be seen on the videos) for 9107 minutes, but that dur- ing this time, he had made numerous pauses for a total of 5354 minutes, which left only 3813 minutes of translating. These numbers (i.e. number of hours worked minus total time spent on pauses) gave us an average speed of 510 words per hour. This number seemed rather high and it seemed as though there must be a more accurate way still to calculate his 'relative' speed. An analysis of pauses allowed this to be calculated more precisely.

\section{Pauses}

I had not only calculated the number of pauses made during the study, but also their length. As noted earlier, I had decided to calculate only those whose length had been at least 3 minutes. This decision was based primarily on the fact that it would not have been feasible to time pauses of a few seconds for such a length of time (152 or so hours) with any reliability, and also, it would have been difficult to distinguish a pause versus a hesitation of such duration. It was necessary for pauses to be long enough for the translator to consult a dictionary or database, a colleague or a client, but not so long so that they might have been used for purposes other than translation.

The translator made 231 pauses during the study lasting from the imposed lower limit of 3 minutes to 6 hours and 29 minutes. This great variability suggested that pauses had different purposes and that a more detailed analysis was necessary. A more in-depth examination revealed two different types of pauses. These were labelled 'internal' and 'external' pauses. The first consisted of pauses whose length varied between 3 and 39 minutes; the second between 3 minutes and 6 hours 29 minutes. The pauses made during a translation were termed internal because they were made during a translation. A pause in the middle of a sentence because of a difficulty encountered, for example, was deemed internal if the translator came back a while later and proceeded with the translation. Those occurring between two different texts, at the beginning or at the end of the day and during the lunch hour ou what were presumably coffee breaks were named external pauses. It seemed likely that a pause made during a job was used for research or information purposes whereas a pause made between two different texts might have been used as a 'break.' Having distinguished these two types of pauses, it would be possible to determine how much time the translator spent 'translating,' i.e. the total work time in a day less the time spent in external pauses. This calculation revealed that the translator spent approximately the same time on translation in the morning and the afternoon. Not only that, he made approximately the same number of internal pauses in the 
morning and the afternoon. This regularity suggested that the translator uses these internal pauses as a break, a means to refresh his mind, in other words, they may be necessary.

Having established a difference between the types of pauses, I calculated the time spent on internal pauses as opposed to external ones and then recalculated the speed of translation. Discounting external pauses, the time passed doing translationrelated work was reduced to 5409 minutes and the speed corrected to 375 words per hour (average over the study). This figure seemed more realistic. However, it should be noted that such a speed could probably not be maintained thoughout the day were it not for the breaks (it would come out to be around 2800 words a day). The Bureau expected most translators at his level to translate around 1800 to 2000 words a day.

\section{MICROSCOPIC ANALYSIS}

Translations were analyzed in more detail in the second part of the study. The macroscopic analysis shed some light on what a translator's day was like, how much time he spent on translation-related duties and how much time was spent on other unidentified duties. It revealed interesting data about the pauses he made and about their extreme regularity, and raised questions about the reliability of speed calculation. However, it did not allow us to determine what happened on a linguistic level. Which types of corrections did the translator make during the course of his work? Did he use any methods consistently? Were there many hesitations or did the translation flow relatively smoothly? It became clear that the texts could not be analyzed out of context. The main reason is normative in character. Translators are subjected to norms when performing their work. Some of these are self-imposed, others are imposed by the work environment. The latter would not have been known to an outsider, making it difficult for such a person to attempt an analysis of the work. Others were textual and linguistic and institutional or inhouse norms. These are discussed further.

In order to get a better idea of the constraints imposed by the administrative process itself, it is essential to include here a brief description of the process through which the translation must pass in the Translation Bureau. The translation is not really the result of a single person's work. A number of people contribute at different steps of the process, and they also are influenced by their own sets of norms, some of which are then imposed on the translator.

\section{Flow process}

Once the text is received by the Bureau, the clerk records some relevant data into a computer program (such as length, due date, client name, etc.) and passes it to the administrator whose job it is to distribute the work to the different translators. At the time of this study, there were approximately ten people translating from English into French. The administrator determined how much work a translator should be doing (based on his proficiency, experience and availability). Once the translator received the text, he translated it and, depending on his experience, decided whether it should be proofread or 'revised' by a 'quality controller.' Once the corrections were made to the initial translation, the text went back to the translator for 'approval' and to the clerks who entered the corrections directly on screen. After the clerks entered the corrections, the text was returned to the translator who made sure everything was right and he then put the translation in the director's inbasket. The director had the final say and could decide to add more corrections, making the translation loop back to the pool and the process start all over from this point. All in all, a lengthy process, and one which causes a number of interruptions in the translator's day (some of which would be accounted for by the frequent pauses he makes). At each interruption, he would have to make judgment calls and read the translation then get on with his other work in progress.

\section{Analysis}

The segments chosen for analysis were viewed several times. Details were noted using certain symbols. Pauses were represented by the mathematical intersection symbol or $\cap$. Several of these side by side signified a longer pause whose length would have to be calculated. The letters RT were used every time the translator searched Termium, and RGR in the Grand Robert électronique. The empty set symbol $\varnothing$ signified the search had been fruitless. Finally, internal pauses were symbolized by PI and external ones by PE. Then, when the translator went back over a portion of the text, the change was indicated right below the line where he had stopped, as can be seen in the example below. The modification is underlined. Finally, the version of the translation being worked on was indicated. This was particularly important especially when dealing with the longest text, the Weather Almanac (see below). The abbreviation TÉ (traduction à l'écran) stood for on-screen translation, B(rouillon) 1, B2, B3, for 1st, 2nd, 3rd draft, E(bauche) 1, E2, E3 for 1 st, 2nd or 3rd proof and $\mathrm{V}$ (ersion) $\mathrm{P}$ (ubliée) for published version. 
The following example demonstrates how a sentence might evolve:

'As temperatures exceeded $10^{\circ}$ in the south, the unusually deep snow from the previous 2 months began to melt rapidly.'

1. Les températures de plus de $10^{\circ}$ (TÉ)

2. Les températures supérieures à $10^{\circ}$ dans le sud font fondre l' $\cap$ (TÉ)

3. En peu de temps, les quelques deux (TÉ)

4. En peu de temps, la neige p (TÉ)

5. En peu de temps, l'abondante neige accumulée sur deux mois commencent à fondre en raison des (températures supérieures à $10^{\circ}$ ) (TÉ)

6. En peu de temps, l'abondante neige accumulée sur deux mois commence à fondre en raison des températures supérieures à 10 (B1)

This example is taken from a very interesting text the translator was asked to translate. It was called the Weather Almanac which is in fact a calendar published every year by Environment Canada. This was the longest text worked on during the study, requiring several days to translate. One of the interesting features of this text was that it had to go through some additional steps and was thus subject to additional normative pressures. As mentioned earlier, the abbreviations used in recording the translation as it was being written were uniformally used for all translations. The only difference with this one was that because it would be published, I not only had access to the translator's first drafts, but to the different proofs as they came back from the publisher with different marks on them. I also had access to the final published form of the text.

\section{Norms}

Many authors have studied norms, organizing them differently according to their view of the translation process. In this study, I examined:

1. textual and linguistic norms

2. some translation strategies
a. pauses
b. mises en relief
c. neutralization
d. passage from the linguistic to the represen- tational level

3. institutional norms i.e. in-house norms

4. client-based norms

\section{Textual and linguistic norms}

Textual norms deal with the text as a whole and ensure coherence whereas linguistic norms deal with more discrete situations. Normative decisions have to be made by the translator or other agents before, during or after the translation.

The fact that press releases must be translated in the present tense in French, or that the claimant's age must be written in full for presentations before the Canada Pension Plan Review Tribunal are examples of textual norms. Some of these become internalized and thus automatic, while others do not. Norms are sometimes selfimposed, or they may be imposed by an external agent. Some norms are necessary to ensure uniformity as is the case of a longer text like the Weather Almanac. The decision to capitalize geographical directions, for example, was not so much for grammatical reasons as for the sake of uniformity. This decision was thus the product of an institutional norm. There can be some overlap between norms, some being construed as personal or as institutional, depending on the point of view. The prevalence of norms and their inescapability can be highly significant.

Linguistic norms are associated with specific situations or specific expressions. Examples of this would be the translation of the preposition with or as. There are numerous ways to translate these prepositions and the translator must determine which one produces the best translation.

The following example illustrates how the translator dealt with the preposition as in a passage of the Weather Almanac. Here is the English:

'As temperatures exceeded $10^{\circ}$ in the south, the unusually deep snow from the previous 2 months began to melt rapidly.'

The translator's attempt at translating the as were as follows:

1. Les températures de plus de $10^{\circ}$ (TÉ)

2. Les températures supérieures à $10^{\circ}$ dans le sud font fondre l'«(TÉ)

3. En peu de temps, les quelques deux (TÉ)

4. En peu de temps, la neige p (TÉ)

5. En peu de temps, l'abondante neige accumulée sur deux mois commencent à fondre en raison des (températures supérieures à $10^{\circ}$ ) (TÉ)

6. En peu de temps, l'abondante neige accumulée sur deux mois commence à fondre en raison des températures supérieures à $10^{\circ}$ (B1) (Underlined words indicate changes made by the translator; bold ones attempts at translating the preposition).

In this example, the preposition does not introduce a comparison but expresses a consequence. The translator first renders it by a verbal construction, 'font fondre' - one of the solutions proposed by Delisle (1993). This doesn't satisfy him so he introduces a filler (étoffement): 'En peu 
de temps,...' Finally, he finds a satisfactory solution: '...en raison des températures supérieures à 10. 'What motivated his choice? The translator changes the perspective and emphasizes one element over another. In this case, he chooses to focus on the snow melt rather than on the warm temperatures. He could have done the opposite. In Langacker's (1983) cognitive grammar, the emphasized element or figure would be the melting snow and the ground, the warm temperatures.

This is but one interpretation of an aspect of the translator's reasoning. Although there is no way of knowing exactly what he was thinking, this example does illustrates that the translator explores a variety of strategies until one seems appropriate. Sometimes a word or expression triggers an automatic response attributable to his upbringing, his training or his experience or a combination of these and/or other factors; at other times he changes his perspective.

Here are a few of the other strategies used: pauses; emphasis; neutralization and passage from the linguistic to the representational level (change of perspective).

\section{Strategies}

\section{Pauses}

Pauses acted as natural breaks between jobs and periods in the day. They were also used as a strategy. In another segment of the Weather Almanac:

February 5 1997: 'Mountains of ice, swept by high winds, poured over breakwalls [...].'

'Le 5 février $\cap \cap$ 1997: Des montagnes de glace, $\cap$ poussées par les $\cap \cap$

(PI - 7 minutes)

de violentes bourasques, ont $\cap \cap \cap$ traversé les brise-lames'

(PI - 30 minutes)

In this segment, the translator made two internal pauses. Neither came at the end of his sentence. Does this mean that the phone rang or that a colleague interrupted him? Or does it mean that he created the interruption, perhaps because he needed a break? The first pause occurred right in the middle of the date. He therefore had not begun to translate the passage itself. After a 7 minute pause, he continued translating. We cannot know the reason for this pause. The second, however, occurred after the auxiliary verb 'avoir.' The sentence was left unfinished. There was a 30 minute pause. This pause seemed to coincide with a coffee break since it occurred between 9:57 a.m. and 10:27 a.m. Perhaps he was compelled to take it because he needed to take a break - to look at things from a fresh perspective. When he resumed his work, there was another 13 second pause (hesitation?). Was he consulting a dictionary? He then looked up the term 'break-walls' in Termium. He stops again for 30 seconds and looks up the term 'pour over' in Termium. His search seems fruitless but he returns to the text and immediately types 'traversé les brise-lames.' He seems to have found a solution during his pause since he types it directly.

The previous example illustrated how the translator might use pauses to solve problems. Not only can he look up terms in dictionaries, but he can consult colleagues or just take a break in order to just sit and think.

\section{Emphasis}

This second strategy is useful when the resulting translation is likely to be 'tedious.' For example:

'The heavy snowfall resulted in... (list of events)'

In French, the translator would have to use a preposition such as 'à' or 'de' in his enumeration, which would make the sentence long and tedious. He opts for the following solution:

'Bilan des averses abondantes: (he then lists all the events).'

\section{Neutralization}

This third strategy, referred to as 'neutralisation' by Dancette $^{1}$ could be called an avoidance strategy. It is particularly useful when the translator does not wish to solve a difficult problem immediately but wants to come back to it later. He might, for example, insert a series of x's.

'In Calgary, where considerable street flooding occurred, side streets were described as a "huge slurpee".

'Huge slurpee' is obviously the difficulty here, one can understand the kind of problem one would have translating it. His choice is to postpone dealing with it, inserting x's so that he can easily come back to it later using his word processor' search function.

\section{Passage from the linguistic to the representa- tional perspective}

The fourth and final strategy is simply passing from one point of view to another. For example:

'A disastrous fire broke out in Saint-John when a sudden gale arose as a settler was setting fire to some brush.'

Here is how the translation takes shape:

1. 'Un terrible incendie survient à Saint-John lorsqu'un colon...'

2. 'Un terrible incendie survient à Saint-John lorsqu'une rafale soudaine alimente un feu commencé par un cultivateur qui...' 
3. À Saint-John, un cultivateur brûle des branches mortes lorsqu'une rafale soudaine emporte les flammes et...'

4. À Saint-John, un cultivateur brûle des branches mortes lorsqu'une rafale soudaine se produit.

5. À Saint-John, un cultivateur brûle des branches mortes lorsqu'une rafale soudaine se lève.

The translator first translates the verb 'broke out' by 'survenir.' He evidently starts by translating word for word. 'Un terrible incendie survient à Saint-John lorsqu'un colon...' He pauses and starts again, probably because he doesn't like his choice of 'colon.' He changes perspective. Rather than have the fire suddenly break out, and thus emphasizing the fire itself, he decides to focus on the gale and the fact that the two events take place simultaneously, the settler burning some dead brush and the gale arising. He finally changes his choice of verbs, 'se produit' becomes 'se lève,' a more appropriate co-occurrent.

Textual and linguistic norms illustrate the importance of the constraints imposed by the translator himself or by other agents. Strategies used by the translator indicate how the translator solves different problems as they arise. In the next section, I will look at a few examples of institutional norms.

\section{Institutional norms or in-house norms}

Institutional norms are mostly imposed to ensure uniformity. In a translation office, it is reasonable to have all translators adhering to the same norms. It gives the institution or company a more professional look. When the norms are imposed by a particular client, these may seem more frivolous. However, these people may be imposing an institutional norm imposed on them by their institution or company.

One particular client actually gave the translators a two page list of terms to be used in any press release translated for her department. For example, this client wanted the term 'culvert' translated by 'ponceau' not 'buse.' This client also did not want the following expressions used: 'Selon M. Untel' or 'D'ajouter de dire....' These are correct in French, but she did not wish them to be used. These are cases where norms might seem frivolous. Other norms are less frivolous and have a precise function. The term 'resident' can be translated as 'résident' and 'résidant.' Most people use the two interchangeably. However, a quick check in the Petit Robert (1995) reveals that the spelling 'résident' is used to refer to a person established in a country different from his or her coun- try of residence whereas 'résidant' is more general, referring to a person residing somewhere. If one were to strictly adhere to these definitions, it is plain to see it would be preferable to use 'résidant' every time one is not sure what the person's or persons' origin was. In practice, however, there seems to be a preference for the spelling 'résident.'

\section{CONCLUSION}

This study enabled us to 'see' a translator at work, to determine how much time he spent in translation proper and how much time was spent on 'other' activities. The macroscopic analysis revealed many interesting elements such as how fast the translator could translate different texts, the number of times he came back to work on a text and so on. It was not possible to discuss all the findings here, but the reader is referred to MallochHébert (1999) for more details. It also was made clear that the process should not be viewed out of context - a context in which translators are now forced to translate more and faster with more sophisticated electronic tools.

The study of pauses was particularly interesting. Not only was it possible to distinguish internal versus external pauses, but the internal pauses were seen to be very regular, suggesting this to be a strategy - a way to take a step back and return with a fresh perspective. Efforts to make translators use their time more productively, i.e. never chat with colleagues or read the newspaper may actually be counterproductive as these activities may be necessary. Without them, the translator may not be as productive or as effective. As noted before, translating 375 words per hour is possible, but not all day long. This reprieve from the constant mental effort may be necessary. As we saw, this translator, although he spent only $50 \%$ of his time translating was very effective in his work. He was one of the fastest translators in the unit and also spent some of his time revising and doing other activities. Another important finding related to speed. This study shows there are several ways to calculate the speed of translation, but that the one used most widely, called here 'theoretic speed' was in itself not very useful except, perhaps, to establish the inferior limit for a translator.

At a more microscopic level, it became clear that the environment in which a translator works in part determines the process. This study described various strategies employed by the translator to solve different kinds of translation or terminological problems. There are undoubtedly many more. More needs to be done to reveal the countless norms and constraints moulding the translator and making him who he is. This study reveals 
many areas of research which have not been explored because of the time involved. This kind of work is time-consuming and expensive, but the amount of data it produces justifies the cost.

\section{Louise Hébert-Malloch Louise Malloch Translation Services, Etobicoke, Canada lmalloch@sympatico.ca}

\section{NOTES}

1. Dancette, J. (1997:102): 'Neutralisation: une des nombreuses stratégies d'évitement employée surtout par les traducteurs d'expérience. La stratégie permet au traducteur de reporter un problème à plus tard, ce qui lui évite une interruption inopportune.'

\section{REFERENCES}

Dancette, J. (1997): "Mapping Meaning and Comprehension in Translation: Theoretical and Experimental Issues" in Cognitive Processes in Translation and Interpreting, J.H. Danks, G.M. Shreve, S.B. Fountain and M.K. McBeath (eds) Sage Publications.

Delisle, J. (1993): La traduction raisonnée, Les Presses de l'Université d'Ottawa.

Fraser, J. (1993): “Public Accounts: Using Verbal Protocols to Investigate Community Translation," Applied Linguistics 14-4, pp. 325-43.

Fraser, J. (1994): "Translating Practice into Theory: A Practical Study of Quality in Translator Training," in Catriona Picken (ed) ITI Conference 7 Proceedings, London, Institute of Translation and Interpreting.

FRASER, J. (1996a): "The translator Investigated: Learning from Translation Process Analysis," The Translator 2-1, pp. 65-79.

Fraser, J. (1996b): "Mapping the Process of Translation," Meta 41-1, pp. 84-96.

Gerloff, P. A. (1988): "From French to English: A Look at the Translation Process in Students, Bilinguals and Professional Translators," Ph.D. Thesis, Harvard University.

GiLe, D. (1995): "Fidelity Assessment in Consecutive Interpretation: An Experiment,” Target 7-1, pp. 151164.

Hébert-Malloch, L. (1999): “Construction de l'objet 'intraculture' en milieu institutionnel," Unpublished Master's Thesis, Glendon College, York University.

JÄÄSKeläInEN, R. (1987): “What Happens in a Translation Process: Think-aloud Protocols of Translation," Unpublished Pro Gradu Thesis, Finland: Savonlinna School of Translation Studies, University of Joensu.

JäÄSKELÄINEN (1993): "Investigating Translation Strategies," in Sonja Tirkkonen-Condit and John Laffling (eds), Recent Trends in Empirical Translation Research, Studies in Languages, Joensuu, Finland: Faculty of Arts.
JÄÄSKELÄINEN (1996): "Hard work will Bear Beautiful Fruit. A Comparison of Two Think-Aloud Protocol Studies," Meta 41-1, pp. 60-74.

KöNIGS, F. G. (1987): "Was beim Übersetzen passiert. Theoretische Aspekte, empirische Befunde und praktische Konsequenzen" (What Happens in Translation: Theoretical Aspects, Empirical Findings and Practical Consequences), Die Neueren Sprachen, 86(2), pp. 162-85.

Königs F. G. and R. Kaufmann (1996): "Processus mentaux étudiés chez des sujets allemands apprenant le français lorsqu'ils sont en train de traduire. Résultats d'une petite étude de cas comme contribution à la didactique de la traduction et de l'enseignement des langues étrangères," Meta 41-1, pp. 7-25.

KRINGS, H. P. (1986): Was in den Köpfen von Überstezern vorgeht: eine Untersuchung zur Strucktur des Übersetzungsprozesses an fortgestchrittenen Französischlernern (What Happens in the Minds of Translators: An Empirical Study of the Structure of the Translation Process among Advanced Learners of French), Tübingen, Gunter Narr.

LAngacker, R. W. (1983): Foundations of Cognitive Grammar, I: Orientation, II: Semantic Structure, Trier, LAUT.

LÖRSCHer, W. (1991): Translation Performance, Translation Process and Translation Strategies. A Psycholinguistic Investigation, Tübingen, Gunter Narr.

Lörscher, W. (1992a): "Investigating the Translation Process," Meta 37-3, pp. 426-39.

LöRSCHER, W. (1992b): "Process-oriented Research into Translation and Implications for Translation Teaching," Traduction, Terminologie, Rédaction 5-1, pp. 145-61.

Lörscher, W. (1993): “Translation Process Analysis” in Y. Gambier and J. Tommola (eds), Translation and Knowledge: Proceedings of the 1992 Scandinavian Symposium on Translation Theory, Turku: Centre for Translation and Interpreting, University of Turku.

Le Robert (1995), dictionnaire de la langue française, Dictionnaires Le Robert, Paris.

SÉguinot, C. (ed) (1989): The Translation Process, Toronto: H. G. Publications.

SÉguinot, C. (1991): "A Study of Student Translation Strategies" in Sonja Tirkkonen-Condit (ed) Empirical Research in Translation and Intercultural Studies, Tübingen, Gunter Narr.

SÉguinot, C. (1996): "Some Thoughts about ThinkAloud Protocols," Target 8-1, pp. 75-95.

TirkKonen-Condit, S. (1989): "Professional Versus Non-professional Translation: A Think-Aloud Protocol Study," in Candace Séguinot (ed) The Translation Process, Toronto: H. G. Publications.

TirkKonen-Condit (1997): "Who Verbalizes What: A Linguistic Analysis of TAP texts," Target 9-1, pp. 6984.

Toury, G. (1995): Descriptive Translation Studies and beyond, John Benjamins Publishing Company, Amsterdam/Philadelphia. 